\title{
Camu-camu Root Distribution under Different Nitrogen and Potassium Doses through Drip Fertigation
}

\author{
Valdinar Ferreira Melo ${ }^{1}$ \\ Federal University of Roraima-UFRR, Campus Cauamé, BR 174, Km 12, \\ Monte Cristo, Cep: 69300-000 Boa Vista/RR, Brazil
}

\section{Edvan Alves Chagas}

Brazilian Corporation of Agricultural Research (Embrapa), Rodovia, BR 174, Km 8, Distrito Industrial, Caixa Postal: 133, CEP: 69301-970, Boa Vista/RR, Brazil (Productivity Research Scholarship - CNPq)

\section{Raphael Henrique da Silva Siqueira}

Federal Institute of Education, Science and Technology of Roraima, Campus Amajari, Rodovia Antonino Menezes da Silva, Km 03, CEP: 69343-000, Amajari - RR, Brazil

\section{Olisson Mesquita de Souza}

Post-Graduate in Agronomy Program (CCA/UFRR)-POSAGRO, Campus Cauamé, BR 174, Km 12, Monte Cristo, Cep: 69300-000 Boa Vista/RR, Brazil

\section{Luís Felipe Paes de Almeida}

Federal University of Roraima, Campus Paricarana, Insikiran Institute of Higher Education Indigenous, Av. Cap. Ene Garcez, 2413, Bairro Aeroporto Cep: 69310-000 Boa Vista/RR, Brazil

\section{Diogo Francisco Rossoni}

State University of Maringá, Av. Colombo, 5790 - Jd. Universitário CEP 87020-900 - Maringá - PR - Brazil

\section{Pollyana Cardoso Chagas}

Federal University of Roraima (UFRR), Campus Cauamé, BR 174, Km 12, Monte Cristo, Cep: 69300-000 Boa Vista/RR, Brazil

\section{Carlos Abanto-Rodríguez}

Post-Graduate in Biodiversity and Biotechnology Program - Rede Bionorte and Researcher at Researchs Institute of the Peruvian Amazon (IIAP), Carretera Federico Basadre, km 12, 400, Yarinacocha, Ucayali, Peru

Additional index words. Myrciaria dubia (Kunth) McVaugh, nondestructive spatial analysis, caçari, irrigation, root assessment

Abstract. Camu-camu is an native species in domestication processes. Therefore, studies related to the root system are necessary to evaluate the best cultivation practices for an orchard. Two trials were conducted, one with nitrogen $(N)$ and the other with potassium $(K)$, at doses of $0,40,80,160$, and $320 \mathrm{~kg} \cdot \mathrm{ha}^{-1}$. Root distribution was determined using nondestructive analyses in which two-dimensional (2D) root images were obtained from trenches under the plants' canopy. Variables included width (measured in cubic millimeters), area (measured in square millimeters), and length (measured in millimeters, and were analyzed using Safira software (version 2010, Embrapa, Brazil). To have better spatial visualization of variable distribution in the soil profile, data were analyzed using the ordinary kriging technique with the geo $R$ software package and $R$ software (version 2016). Both $N$ and $K$ doses influenced positively the camu-camu root system with regard to length, volume, and area. Better root distribution was verified with $80 \mathrm{~kg} \cdot \mathrm{ha}^{-1} \mathrm{~N}$ and $160 \mathrm{~kg} \cdot \mathrm{ha}^{-1} \mathrm{~K}$ doses. The nondestructive analysis via $2 \mathrm{D}$ images allowed sound characterization of root spatial distribution.

Camu-camu is an native species of the Amazon Basin that attracts attention as a result of its high content of vitamin $\mathrm{C}$, reaching up to $7355 \mathrm{mg} / 100 \mathrm{~g}$ pulp in native populations of Roraima State (Chagas et al., 2015). It is currently considered functional food, with nutraceutical properties such as phenolic compounds and antioxidant substances such as ascorbic acid. These substances are capable of neutralizing excess free radicals caused by most degenerative diseases, such as diabetes, atherosclerosis, and osteoporosis, and those associated with cancer (Chatterjee et al.,1975; Damazio et al., 2017; Thomas, 2000).

The fruit tree is typical of humid tropical climates and is found naturally in the following countries: Peru, Colombia, Venezuela, and Brazil, along riverbanks, lakes, floodplains, and igapós (Pinedo et al., 2010; Smiderle and Sousa, 2010; Yuyama and Valente, 2011).

In Roraima, the northernmost state of Brazil, the occurrence of native camu-camu populations is significant, but the fruit availability is not continuous because of its seasonal production, which is influenced by edaphoclimatic factors (Abanto-Rodríguez et al., 2014). In addition, because the domestication process is still occurring, investigation of the development of agronomic techniques is needed for camu-camu adaptation in upland conditions.

The study of root distribution in the soil profile, with regard to depth and horizontal distance from the trunk, contributes to soil depth preparation, fertilizer and water application, the planning of moisture sensors and sampling sites, and the installation of the number of emitters in localized irrigation systems (Lourenção et al., 2004). Robinson and Sauco (2010) reported that root distribution is influenced strongly by a series of complex and dynamic processes, such as soil type, porosity, and compaction; toxicity of chemical elements; waterlogging and water availability; and nutrients.

Fertigation management in crops can be an alternative for optimal nutrient absorption and loss reduction. However, to verify the performance of the fertigation system it is necessary to evaluate its viability. One of the instruments that has been used to do this is root system distribution analysis. With the advancement of computing, methods and equipment have been developed and used to evaluate the spatial distribution of root systems in the soil profile. Among these methods is a nondestructive analysis, which is performed through digitalized root images in soil profiles obtained from trenches (kriging techniques). This method has less sample effort, lower cost, greater higher precision, and shorter analysis time (Carducci et al., 2014, Mairhofer et al., 2012).

The objective of our work was to determine the effect of different $\mathrm{N}$ and $\mathrm{K}$ doses applied via drip fertigation on the root distribution of camu-camu plants. The data were analyzed using nondestructive roots images obtained from trenches under the plant canopy.

\section{Materials and Methods}

Our research was carried out from Mar. to Oct. 2016 at the Água Boa Experimental Field, EMBRAPA-RR, Boa Vista, Roraima, Brazil (lat. 02'39'48.94' $\mathrm{N}$; long. 6050'30.39',W; altitude, $90 \mathrm{~m}$ ). The local climate is tropical savanna (Aw) according to the Köppen classification, with an average annual temperature of $27.8{ }^{\circ} \mathrm{C}$ and average annual rainfall of $\approx 1.650 \mathrm{~mm}$. The driest period occurs between the months of December and March $( \pm 9 \%$ annual rainfall), and the wettest months are 

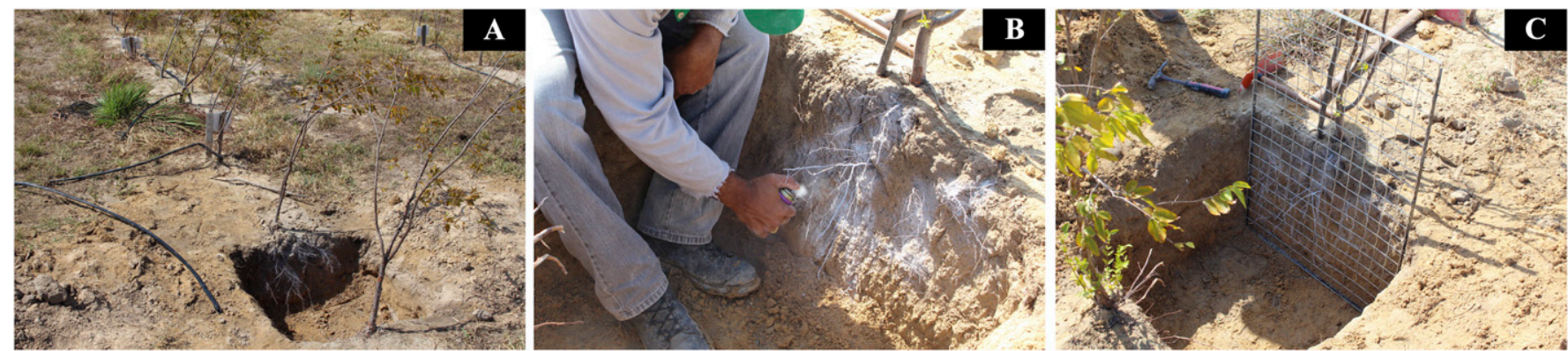

Fig. 1. (A) Trench. (B) Root painting. (C) Grid positioning.

A

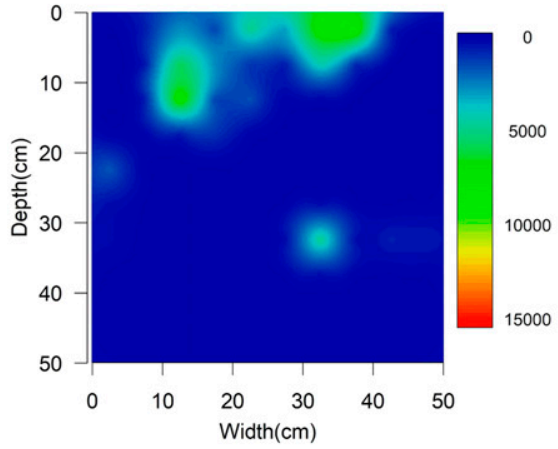

C

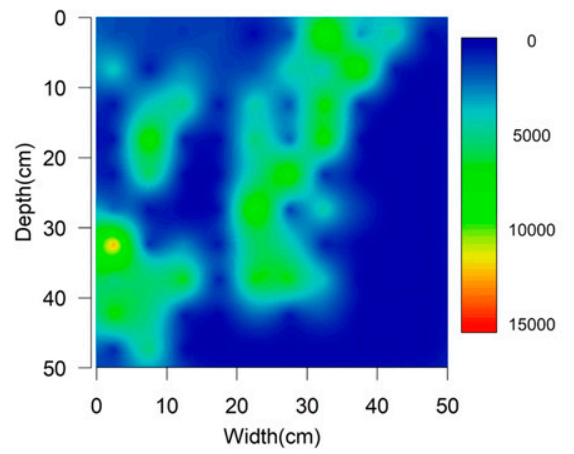

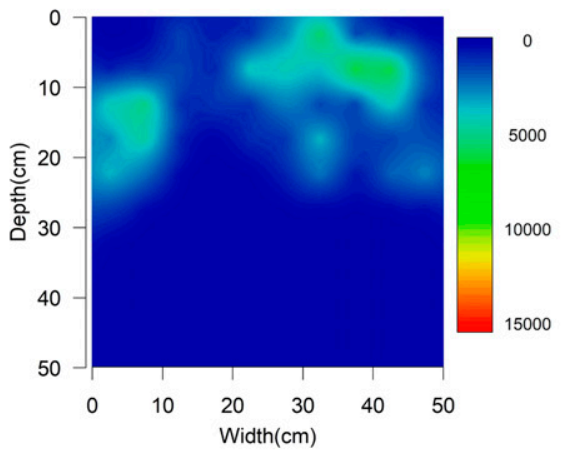

D

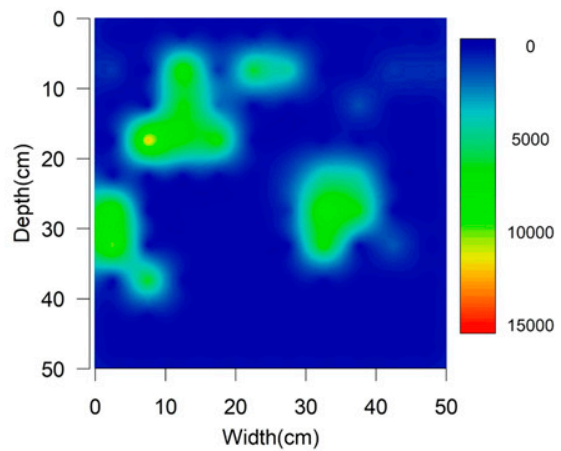

B

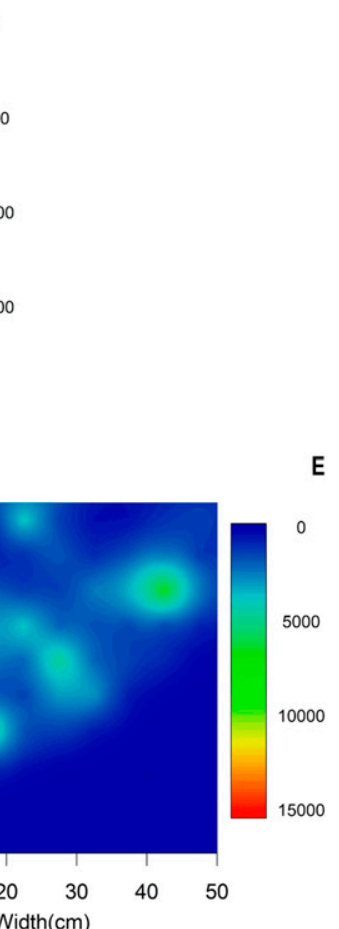

Fig. 2. Camu-camu root volume (measured in cubic millimeters) under fertigation with nitrogen doses of 0 (A), 40 (B), 80 (C), 160 (D), and 320 (E) kg.ha ${ }^{-1}$.

between May and August ( $\pm 70 \%$ annual rainfall) (Barbosa, 1997).

The soil of the experimental field is classified as Oxisol with a $\mathrm{pH}$ of 4.4, organic matter (OM; $\left.10 \mathrm{~g} \cdot \mathrm{kg}^{-1}\right), \mathrm{P}\left(3 \mathrm{~g} \cdot \mathrm{kg}^{-1}\right), \mathrm{K}\left(0.2 \mathrm{Cmol}_{\mathrm{c}} \cdot \mathrm{kg}^{-1}\right), \mathrm{Ca}$ (0.2 Cmolc $\left.\cdot \mathrm{kg}^{-1}\right), \mathrm{Mg}\left(0.1 \mathrm{Cmolc} \cdot \mathrm{kg}^{-1}\right), \mathrm{H}+\mathrm{Al}$ $\left(2.4 \mathrm{Cmolc} \cdot \mathrm{kg}^{-1}\right), \mathrm{SB}\left(0.32 \mathrm{Cmolc} \cdot \mathrm{kgm}^{-1}\right), \mathrm{CEC}$ (2.8 Cmolc $\cdot \mathrm{kg}^{-1}$ ), according to soil chemical analysis manual of EMBRAPA.

Received for publication 8 Aug. 2018. Accepted for publication 17 Dec. 2018.

This study was financed in part by the Coordenação de Aperfeiçoamento de Pessoal de Nível Superior - Brasil (CAPES) - Finance Code (Pró-Amazônia-Process 23038.000715/2013-63) and the National Council for Scientific and Technological Development - CNPq.

We thank Prof. Dr. Carla Eloize Carducci of the Federal University of Grande Dourados (UFGD) for contributions to the best treatment of the data.

${ }^{1}$ Corresponding author. E-mail: valdinar@yahoo. com.br.
Soil preparation consisted of applying dolomitic limestone $\left(800 \mathrm{~kg} \cdot \mathrm{ha}^{-1}\right)$, and after planting, $10 \mathrm{~g} /$ plant FTE-BR12 (fritted trace elements) to provide micronutrients $(9.0 \%$ to $9.2 \%$ zinc, $1.8 \%$ to $2.17 \%$ boron, $0.80 \%$ copper, $3.82 \%$ iron, $2.0 \%$ to $3.4 \%$ manganese, and $0.132 \%$ molybdenum). In addition, weed control was carried out monthly on the orchard.

The irrigation method was characterized by a drip system with a pump connected to a water container, with automatic activation by a RAIN $\mathrm{BIRD}^{\circledR}$ timer. The linear system flow was 6.8 $\mathrm{L} \cdot \mathrm{h}^{-1}\left(3.4 \mathrm{~L} \cdot \mathrm{h}^{-1}\right.$ per dripper spaced every 50 $\mathrm{cm})$. For injection of the fertilizers, a threequarter-inch Venturi-type injector was used, with a $150-\mathrm{L} \cdot \mathrm{h}^{-1}$ injection rate every week.

In this study, two experiments were conducted in a randomized block design with five doses of $\mathrm{N}$ and $\mathrm{K}(0,40,80,160$, and 320 $\left.\mathrm{kg} \cdot \mathrm{ha}^{-1}\right)$ and four replicates. The experiments were installed in 2013, and root system data were measured in 2015, when plants were, on average, $1.50 \mathrm{~m}$ tall and had a trunk diameter of $25 \mathrm{~mm}$. The plant spacing used was $4 \mathrm{~m}$ between rows and $1 \mathrm{~m}$ between plants.

For the root system analysis, 20 trenches were dug (Brasil et al., 2007) (10 for each experiment) at a $0.10-\mathrm{m}$ distance from the trunk at $0.50 \mathrm{~m}$ wide $\times 0.50 \mathrm{~m}$ long $\times 0.50 \mathrm{~m}$ deep. Root distribution was visualized on the vertical wall of the trench under the plant canopy. The soil was scarified along the wall, removing a thin layer of soil $(\approx 0.02 \mathrm{~m})$, and then a water jet was used to expose the roots. After this procedure, the roots were sprayed with white paint to increase the contrast in relation to the ground of the trench wall, and then a metal grid with the trench dimensions was placed in perfect contact with the roots in the vertical wall for taking photographs. The grid consisted of one hundred 5- $\times 5$-cm squares (Fig. 1).

The digital images were made with a semiprofessional digital camera with 32megapixel resolution. To have a better quality image, the trench was covered with a black cloth to avoid contrast from reflected 


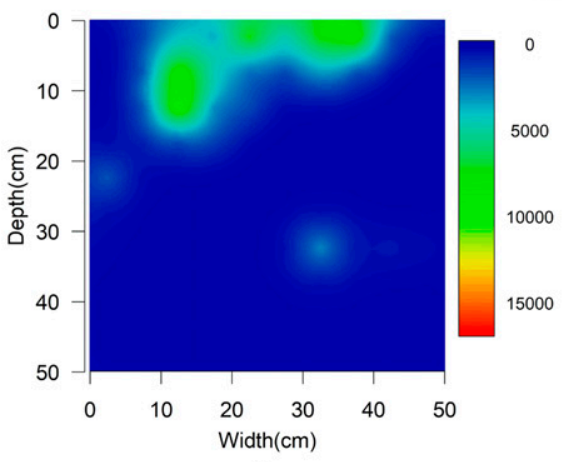

C

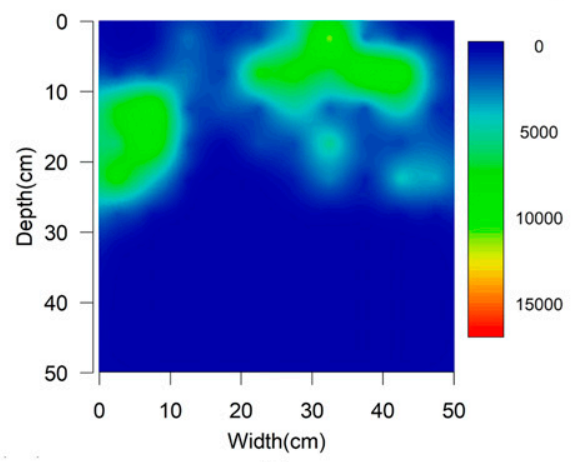

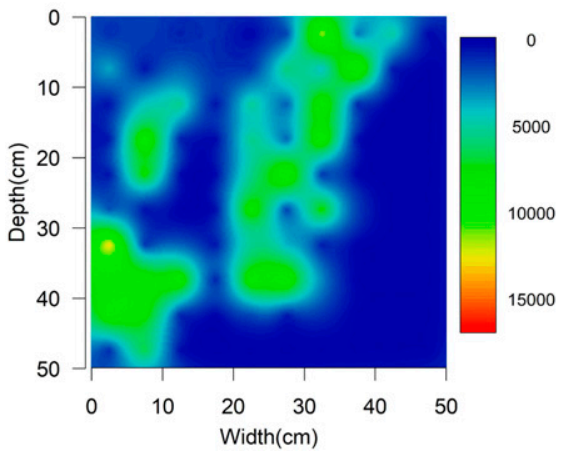

Fig. 3. Camu-camu root area (measured in square millimeters) under nitrogen fertigation doses of 0 (A), 40 (B), 80 (C), 160 (D), and 320 (E) kg.ha ${ }^{-1}$.

A

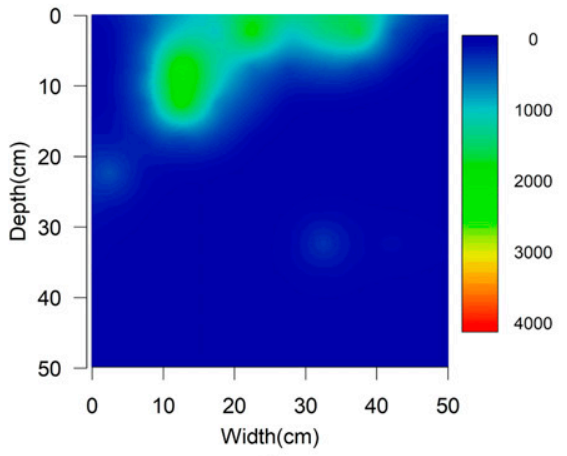

C

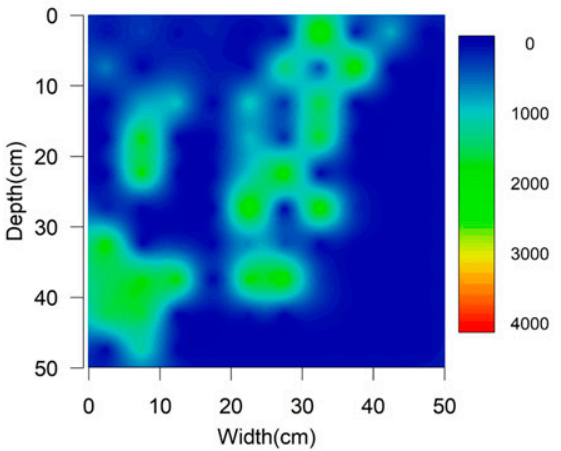

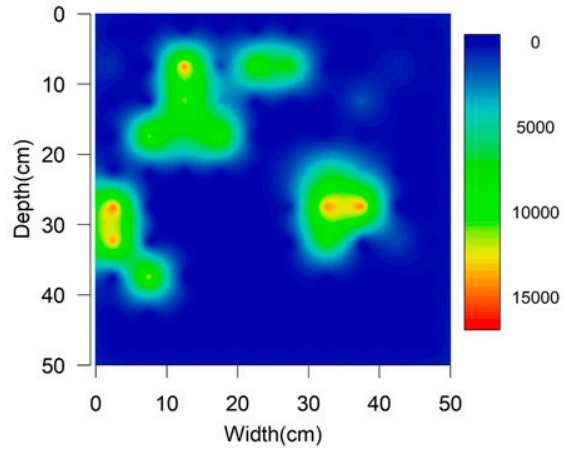

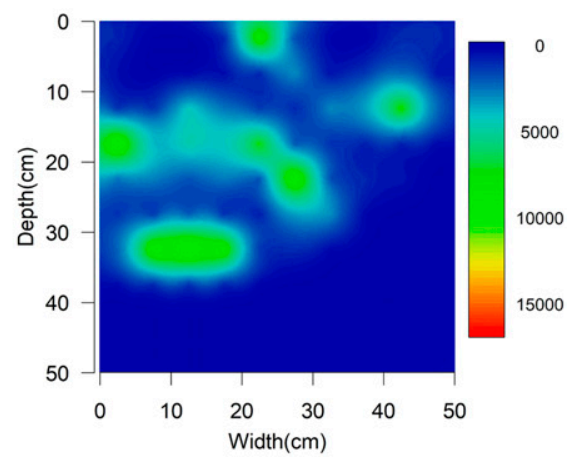

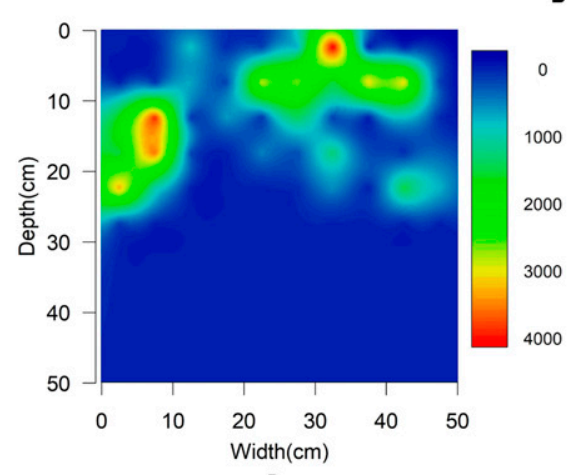

D
E

000

000

000

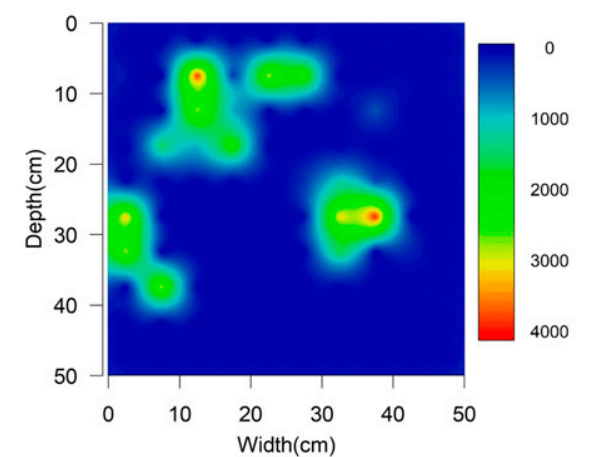

B

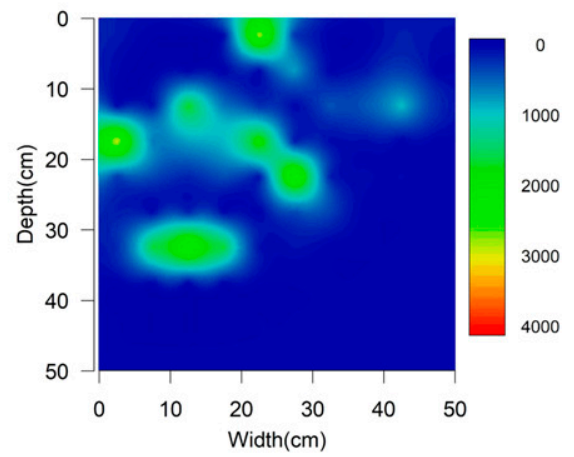

Fig. 4. Camu-camu root length (measured in millimeters) under nitrogen fertigation doses of 0 (A), 40 (B), 80 (C), 160 (D), and 320 (E) kg.ha ${ }^{-1}$.

sunlight. Afterward, the images were corrected and aligned using Microsoft Office Picture Manager software (version 2013). Quantification of the root variables of volume (measured in cubic millimeters), surface area HortScience Vol. 54(4) ApriL 2019 (measured in square millimeters), and length (measured in millimeters) was done using Safira software (Jorge and Silva, 2010).

With the results obtained for each grid unit, we proceeded to estimate the sample semivariance. For this purpose, the centroid of each plot was used, comprising 100 sample points.

After the model adjustment to the semivariogram, it was possible to estimate the 
A

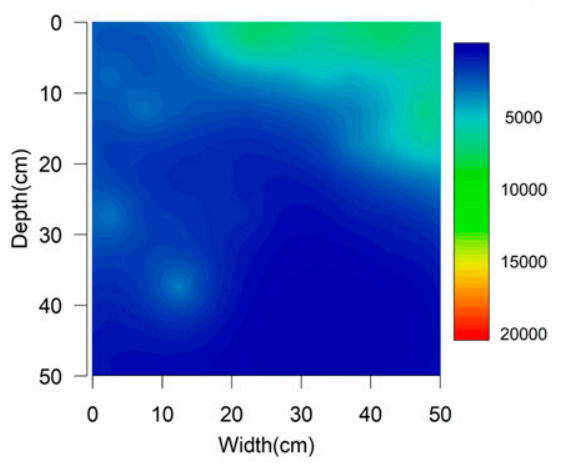

C

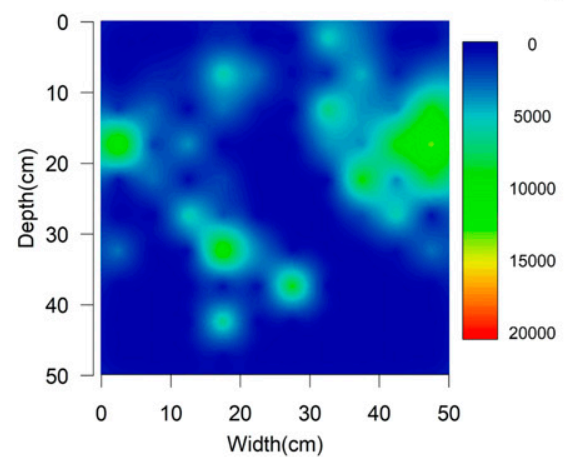

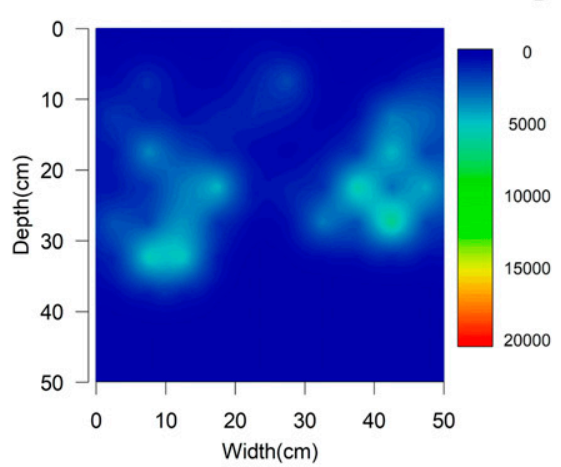

D
E

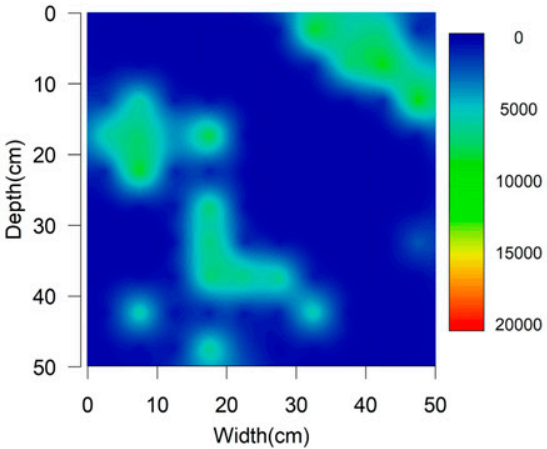

Fig. 5. Camu-camu root volume (measured in cubic millimeters) under potassium fertigation doses of 0 (A), 40 (B), 80 (C), 160 (D), and 320 (E) kg.ha ${ }^{-1}$.
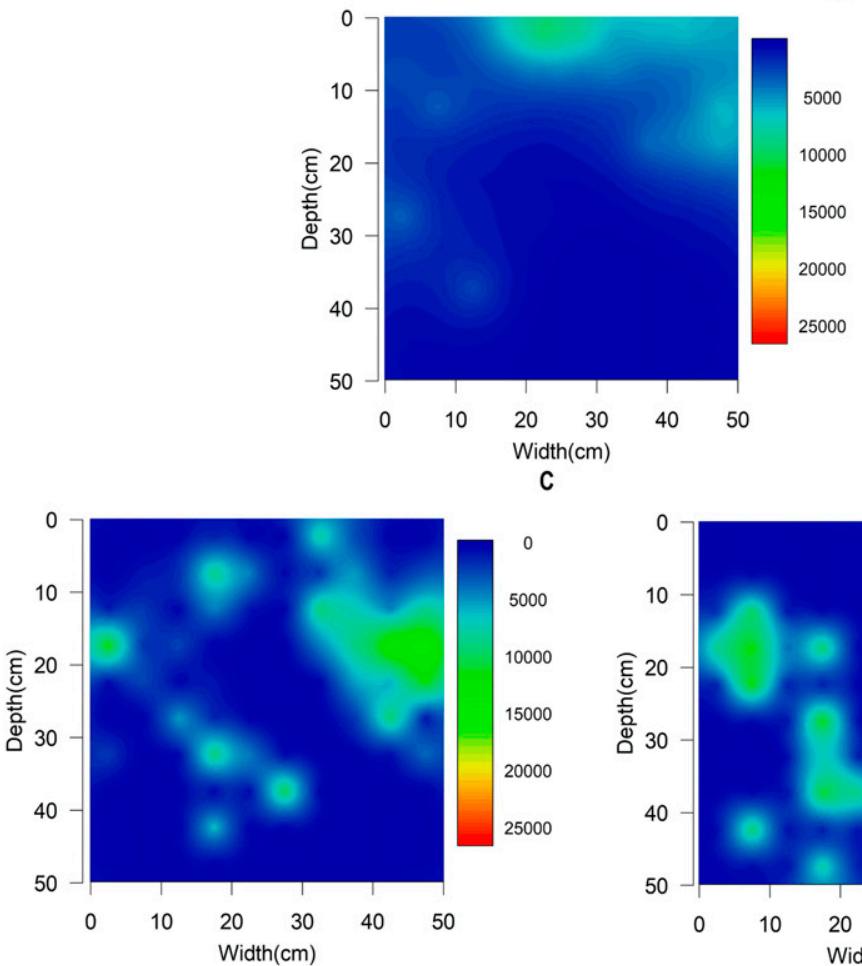

A

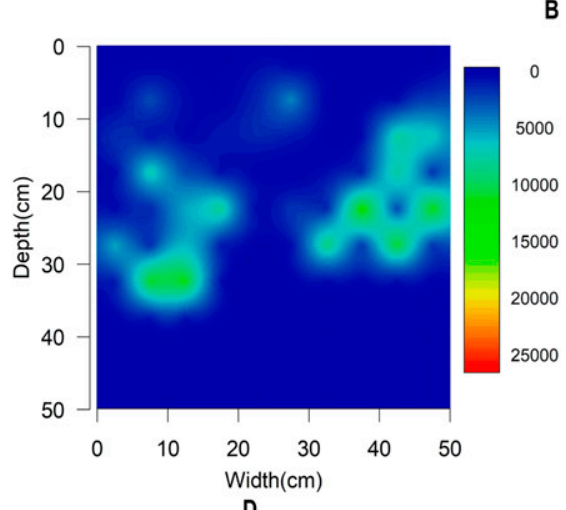

D

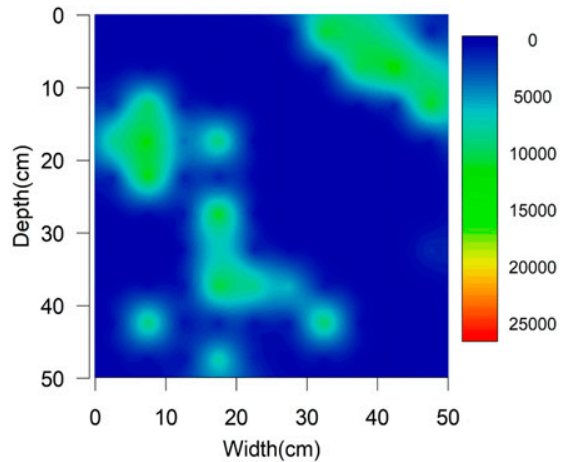

Fig. 6. Camu-camu root area (measured in square millimeters) under potassium fertigation doses of 0 (A), 40 (B), 80 (C), 160 (D), and 320 (E) kg.ha ${ }^{-1}$.

unsampled points to obtain a better visualization of the root distribution in the soil profile. To do this, ordinary kriging using the geoR (Ribeiro and Diggle, 2006) and R (R Core Team, 2016) software packages was performed.

\section{Results}

The camu-camu root system distribution is presented in colored graphs based on digitalized photographs. In this sense, the red color represents the highest concentration of the root system followed by the green and blue color respectively.

Camu-camu root volume $\left(\mathrm{mm}^{3}\right)$, area $\left(\mathrm{mm}^{2}\right)$, and length with increasing $N$ doses fertigation. The predominant root volume ranged from 4000 to $6000 \mathrm{~mm}^{3}$ (green 


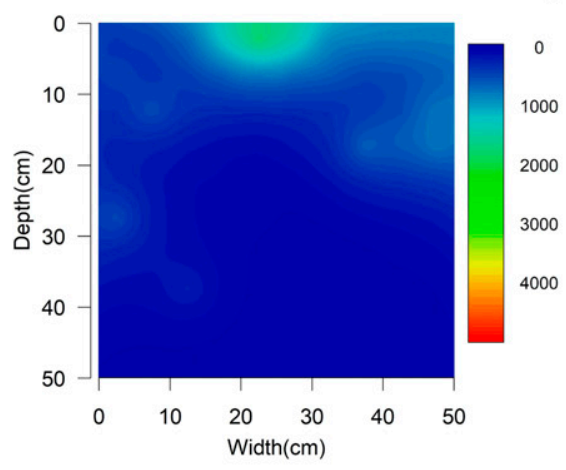

C

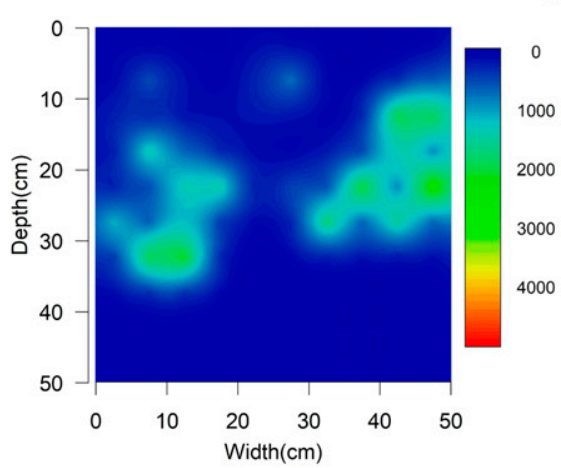

D
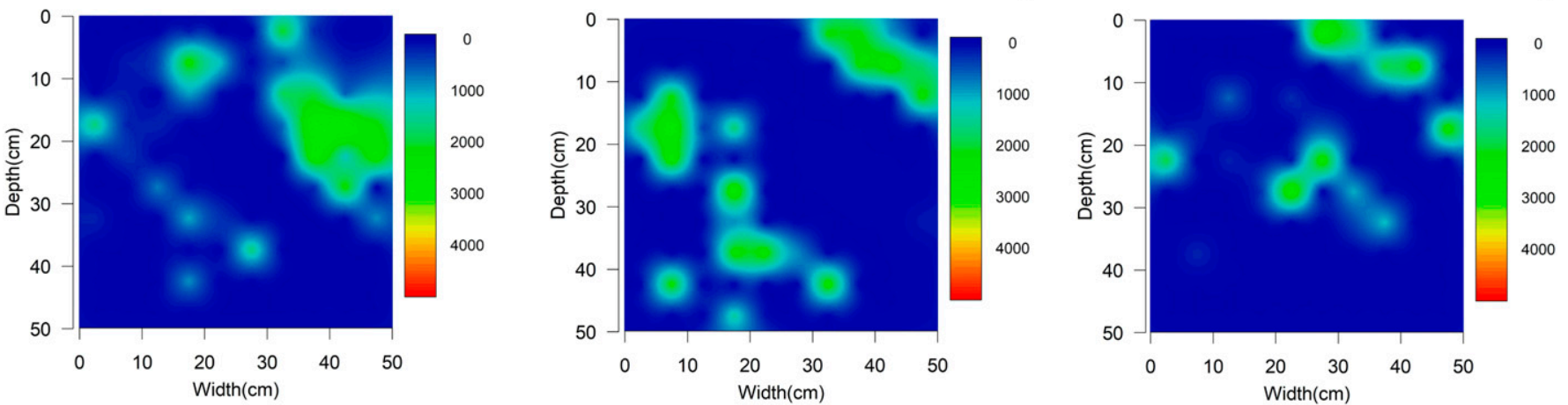

Fig. 7. Camu-camu root length (measured in millimeters) under potassium fertigation doses of 0 (A), 40 (B), 80 (C), 160 (D), and 320 (E) kg.ha ${ }^{-1}$.

color) at a $0.40-\mathrm{m}$ depth and close to a $0.30-\mathrm{m}$ lateral distance at all $\mathrm{N}$ doses. Greater root volumes were noted in the profile (Fig. 2).

The greatest root volume $\left( \pm 12,000 \mathrm{~mm}^{3}\right.$; red color) was recorded near a $0.20-\mathrm{m}$ depth at $160 \mathrm{~kg} \mathrm{~N} / \mathrm{ha} \mathrm{N}$ doses (Fig. 2D). In contrast, at 0 and $40 \mathrm{~kg} \mathrm{~N} / \mathrm{ha} \mathrm{N}$, the root volume was recorded in the first layer of 0 to $0.10 \mathrm{~m}\left( \pm 8000 \mathrm{~mm}^{3}\right)$, and at 80 and $320 \mathrm{~kg}$ $\mathrm{N} /$ ha $\mathrm{N}$, the greatest volume was observed in the layer at 0.30 to $0.40 \mathrm{~m}\left(8000-10,000 \mathrm{~mm}^{3}\right)$ deep. In relation to the root area $\left(\mathrm{mm}^{2}\right)$, camucamu plants presented variation according to increasing doses of $\mathrm{N}$ (Fig. 3). Thus, with 80 $\mathrm{kg} \cdot \mathrm{ha}^{-1} \mathrm{~N}$, roots were better distributed in the profile, reaching deeper regions of up to $0.50 \mathrm{~m}$ (Fig. 3C).

Camu-camu root length ranged from 500 to $10,000 \mathrm{~mm}$ with increasing $\mathrm{N}$ doses (Fig. 4).

The $0 \mathrm{~kg} \mathrm{~N} / \mathrm{ha}$ doses resulted in smaller root length indicating $2500 \mathrm{~mm}$, located predominantly at $0.20 \mathrm{~m}$ deep. The $40 \mathrm{~kg} \mathrm{~N} / \mathrm{ha}$ doses had a slightly increase in root length achieving $4000 \mathrm{~mm}$ and in the $80 \mathrm{~kg} \mathrm{~N} / \mathrm{ha}$ dose roots were found $50 \mathrm{~cm}$ deep in profile with $2000 \mathrm{~mm}$ length. The $160 \mathrm{~kg} \mathrm{~N} / \mathrm{ha}$ and $320 \mathrm{~kg} \mathrm{~N} / \mathrm{ha}$ doses had almost the same the length, from 2000 to $3000 \mathrm{~mm}$ (Fig. 4E). However, those of smaller length (green color) were predominant in all profiles. In general, incremental $\mathrm{N}$ doses allowed for a greater comprehension of the roots distribution in the soil profile, indicating that higher doses $(320 \mathrm{~kg} \mathrm{~N} / \mathrm{ha})$ did not promote root length.

Camu-camu root volume $\left(\mathrm{mm}^{3}\right)$, area $\left(\mathrm{mm}^{2}\right)$, and length with increasing $K$ doses fertigation. The camu-camu root volume showed values ranging from $2000-12,000 \mathrm{~mm}^{3}$, distributed up to $0.5 \mathrm{~m}$ deep, in response to different increasing doses of K (Fig. 5).

It was observed that 0 and $40 \mathrm{~kg} \mathrm{~K} / \mathrm{ha}$ doses induced more superficial root distribution at a $0.35-\mathrm{m}$ depth. However, the greatest root volume $\left(12,000 \mathrm{~mm}^{3}\right)$ was observed with $80 \mathrm{~kg} \mathrm{~K} / \mathrm{ha}$ doses, concentrated at a depth of 0.1 to $0.2 \mathrm{~m}$. In addition, roots were better distributed in the soil profile at $2500 \mathrm{~cm}^{2}$ (Fig. 5).

In Fig. 6, it is observed that the camucamu root area $\left(\mathrm{mm}^{2}\right)$ was influenced by increasing doses of $\mathrm{K}$. Thus, the doses of 0 , 40, 80, and $160 \mathrm{~kg} \mathrm{~K} / \mathrm{ha}$ showed a larger root area, with an approximate value of $10,000 \mathrm{~mm}^{2}$. But, in the first two $\mathrm{K}$ doses, the root distribution had a greater concentration in the first $0.25-\mathrm{m}$ depth.

At 80 and $160 \mathrm{~kg} \cdot \mathrm{ha}^{-1}$ of $\mathrm{K}$ doses, there was a better root distribution in depth that occupied almost the entire area of the soil profile. However, at $320 \mathrm{~kg} \mathrm{~K} / \mathrm{ha}$, the root area was less than with the other doses, with a maximum value of $8000 \mathrm{~mm}^{2}$. Similarly, the root distribution at this dose was up to $0.35 \mathrm{~m}$ deep.

The greatest root length was recorded at 80,160 , and $320 \mathrm{~kg} \mathrm{~K} / \mathrm{ha}$, with values ranging from $2500-8000 \mathrm{~mm}$. In addition, these doses induced better root distribution at depth and width, covering $80 \%$ of the $2500-\mathrm{cm}^{2}$ profile (Fig. 7).

\section{Discussion}

In relation to root volume $\left(\mathrm{mm}^{3}\right)$, it is evident that $\mathrm{N}$ doses up to $160 \mathrm{~kg} \mathrm{~N} / \mathrm{ha}$ increased the root distribution, with a slight reduction in deeper layers. Similar results were verified by Eloi et al. (2004), who worked with different $\mathrm{N}$ doses in Annona muricata and found that the greatest concentration of roots occurred in the superficial layer with a $380-\mathrm{kg} \mathrm{N} / \mathrm{ha}$ dose.

Therefore, the reduction and irregular distribution of roots at greater $\mathrm{N}$ doses (Fig. 1) can be explained by the excessive use of N. Dechen and Nachtigall (2006) describe that plants under these conditions reduce the development of the root system in favor of greater vegetative area.

It was also noticed that the greatest root concentration in the vertical soil profile was asymmetric in relation to the trunk. This fact was triggered by the increased availability of water and nutrients provided through fertigation concentrated on one side of the line. Similar results were obtained by Covre et al. (2015), who worked with Coffea canephora fertigation and discovered that the roots were closer to the drip irrigation line.

The root area variable $\left(\mathrm{mm}^{2}\right)$ with different $\mathrm{N}$ doses, was influenced by $\mathrm{N}$ soil mobility associated with soil moisture, promoting a greater number of roots and, consequently, the capacity to reach relatively deeper layers in search of nutrients and water.

Under these conditions, the camu-camu root system areas were close to $10,000 \mathrm{~mm}^{2}$, but in the treatments without $\mathrm{N}$ and at $40 \mathrm{~kg}$ $\mathrm{N} / \mathrm{ha}$, the roots were concentrated in the first $30-\mathrm{cm}$ depth, while in the other doses the roots exceeded this layer.

According to Marschner and Marschner (2012), the nutrient supply can influence root system growth and distribution, and this 
effect is marked mainly by N. In addition, Silveira and Monteiro (2010) reported that the $\mathrm{N}$ supply to the aerial part is dependent on a well-developed root system.

The results obtained in our work are in agreement with those of Abanto-Rodriguez et al. (2018), who evaluated the total dry weight of camu-camu plants under different $\mathrm{N}$ doses. They demonstrated that there was a greater increase in the total dry weight with about $80 \mathrm{~kg} \cdot \mathrm{ha}^{-1}$ and a growth decrease at greater doses. In this sense, the reduction and irregular distribution of the roots in the greater of $\mathrm{N}$ doses occurred, according to Dechen and Nachtigall (2006), because of the excess of $\mathrm{N}$ in the soil solution, which elevates the osmotic pressure, damaging the absorption of nutrients by roots and reducing vegetative growth.

On the other hand, the effect of $\mathrm{K}$ doses on root growth showed that distribution in volume was influenced by low nutrient supply. Thus, the nutritional imbalance or absence of $\mathrm{K}$ resulted in smaller root systems, concentrated in the superficial profile to take advantage of reduced $\mathrm{K}$ in soil.

According to the results, all $\mathrm{K}$ doses did not influence root system depth, probably because of the continuous availability of water on the surface by the irrigation system.

The smaller root area $\left(\mathrm{mm}^{2}\right)$ associated with lower $\mathrm{K}$ can be explained based on the work of Abanto-Rodríguez et al. (2014), who found less vegetative growth in the absence of or low K doses.

Root length was influenced positively by greater $\mathrm{K}$ doses, which is in agreement with the results of Freitas et al. (2009), who tested different levels of $\mathrm{K}$ in irrigated passionfruit plants, with the greatest doses increasing root length. The 0 - and $40-\mathrm{kg} \cdot \mathrm{ha}^{-1} \mathrm{~K}$ doses did not favor root development, and root length was less than $1500 \mathrm{~mm}$ and was distributed at a depth of $\pm 0.35 \mathrm{~m}$.

\section{Conclusions}

The $\mathrm{N}$ and $\mathrm{K}$ fertigation doses, separately, influence the distribution of root systems in terms of length, volume, and area. The best root distribution was achieved with $80 \mathrm{~kg} \mathrm{~N} / \mathrm{ha}$ and $160 \mathrm{~kg} \mathrm{~K} / \mathrm{ha}$ doses. Nondestructive analysis through 2D images made a complete spatial root system characterization possible. It is recommended to carry out further studies concerning the distribution of the root system of plants of different ages in function of the various types of agronomic management, in order to analyze the adaptation of camu-camu to the conditions external to its natural habitat.

\section{Literature Cited}

Abanto-Rodríguez, C., E.A. Chagas, T.C.S Albuquerque, A.G. Souza, W.F. Araújo, P.C. Chagas, J.K.C. Andrade, and W.M. Souza. 2014. Crescimento inicial de plantas de camu-camu sob fertirrigação com potássio em condições de terra firme. Folia Amazónica 23:7-16.

Abanto-Rodriguez, C., E.A. Chagas, R.E.S. Siqueira, W.F. Araújo, L.C. Zborowski, L.P. Souza, C.S.R.T. Sakasaki, J.L. Monteiro Neto, and J. Sánchez-Choy. 2018. Contenido de nutrientes y fertirrigación en el cultivo del camu (Myrciaria dubia (Kunth) McVaugh) con diferentes dosis de nitrógeno. Acta Agron. 67:79-85.

Barbosa, R.I. 1997. Distribuição das chuvas em Roraima, p. 325-335. In: R.I. Barbosa, E.J. Ferreira, and E.G. Castellon (eds.). Homem, ambiente e ecologia no estado de Roraima. Instituto Nacional de Pesquisas da Amazônia, Manaus, Amazonas.

Brasil, F.C., E. Zonta, and M.R.G. Oliveira. 2007. Métodos de amostragem e quantificação para estudos do sistema radicular em condições de campo: Uma revisão crítica. Rev. Cienc. Vida 27:14-33.

Carducci, C.E., G.C. Oliveria, J.M. Lima, D.F. Rossoni, A.L. Costa, and L.M. Oliveira. 2014. Distribuição espacial das raízes de cafeeiro e dos poros de dois Latossolos sob manejo conservacionista. Rev. Bras. Eng. Agr. Ambient. 18:270-278.

Chagas, E.A., R.M.B. Lozano, P.C. Chagas, C.G. Bacelar-Lima, M.I.R. Garcia, J.V. Oliveira, O.M. Souza, B.S. Morais, and M.C.R. Araújo. 2015. Intraspecific variability of camu-camu fruit in native populations of northern Amazonia. Crop Breed. Appl. Biotechnol. 15:265-271.

Chatterjee, I.B., A.K. Majumber, B.K. Nandi, and N. Subramanian. 1975. Synthesis and some major functions of vitamin $\mathrm{C}$ in animals. Ann. N. Y. Acad. Sci. 258:24-47.

Covre, A.M., F.L. Partelli, I. Gontijo, and M. Zucoloto. 2015. Distribuição do sistema radicular de cafeeiro conilon irrigado e não irrigado. Pesqui. Agropecu. Bras. 50:10061016.

Damazio, L.S., F.R. Silveira, L. Canever, A.A. De Castro, J.M. Estrela, J. Budni, and A.I. Zugno. 2017. The preventive effects of ascorbic acid supplementation on locomotor and acetylcholinesterase activity in an animal model of schizophrenia induced by keta-mine. An. Acad. Bras. Cienc. 89:1133-1141.
Dechen, A.R. and G.R. Nachtigall. 2006. Micronutrientes, p. 327-354. In: M.S. Fernandes (ed.). Nutrição mineral de plantas. Sociedade Brasileira de Ciência do Solo, Viçosa.

Eloi, W.M., V. F. de Sousa, T.V. de A. Viana, A.S. de Andrade Júnior, R.S.F. de Holanda, and R.M.C.M. de Alcântara. 2004. Distribuição espacial do sistema radicular da gravioleira em função de diferentes doses de nitrogênio e potássio aplicadas via água de irrigação. Irriga. Botucatu 9:256-269.

Freitas, C.A.S., C.A.A. Costa, F.M.L. Bezerra, A.A.T. Montenegro, and A.S. Teixeira. 2009. Sistema radicial do maracujazeiro irrigado submetido a diferentes níveis de potássio. Scientia Agraria Curitiba 10:175-183.

Jorge, L.A.C. and D.J.C.B. Silva. 2010. SAFIRA: Manual de utilização. Embrapa CPDIA, São Carlos.

Lourenção, M. dos S., T.J. da Silva, C.R. Silva, M.V. Folegatti, and J. . Alves Júnior. 2004. Distribuição do sistema radicular de plantas jovens de Lima ácida 'Tahiti' sob diferentes níveis de irrigação. Irriga. Botucatu 9:270-281.

Mairhofer, S., S. Zappala, S.R. Tracy, C. Sturrock, M. Bennett, S.J. Mooney, and T. Pridmore. 2012. RooTrak: Automated recovery of threedimensional plant root architecture in soil from $\mathrm{X}$-ray microcomputed tomography images using visual tracking. Plant Physiol. 158:561-569.

Marschner, H. and P. Marschner. 2012. Mineral nutrition of higher plants. 3rd ed. Academic Press, London, UK.

Pinedo, P.M., V.C. Delgado, P.R. Farroñay, C.S Imán, V.J. Villacrés, M.L. Faching, C.C. Oliva, R.C. Abanto, L.R. Bardales, and V.R. Vega. 2010. Camu-camu (Myrciaria dubia - Myrtaceae): Aportes para su aprovechamiento sostenible en la Amazonía Peruana. 1st ed. IIAP, Iquitos, Perú.

R Core Team. 2016. R: A language and environment for statistical computing. R Foundation for Statistical Computing, Vienna, Austria.

Ribeiro, J.R. and P.J. Diggle. 2006. GeoR: A package for geostatistical analysis. R News 1(2):24.

Robinson, J.C. and V.G. Sauco. 2010. Banana and plantains. 2nd ed. CAB International, Wallingford, UK.

Silveira, C.P. and F.A. Monteiro. 2010. Macronutrientes em folhas diagnósticas o capimtanzânia adubado com nitrogênio e cálcio. Rev. Bras. Zootec. 39:736-745.

Smiderle, O. and R. Sousa. 2010. Teor de vitamina $\mathrm{C}$ e características físicas do camu-camu em dois estádios de maturação. Revista Agroambiente Online (Bergh.) 2:61-63.

Thomas, M.J. 2000. The role of free radicals and antioxidants. Nutrition 16:716-718.

Yuyama, K. and J.P. Valente. 2011. Camu-camu, Myrciaria dubia (Kunth) Mc Vaugh. 1st ed. Curitiba, Brasil. 